\title{
Characterization of Used Lubricant Oil in a Latin-American Medium-Size City and Analysis of Options for Its Regeneration
}

\author{
Carlos Sánchez-Alvarracín *, Jessica Criollo-Bravo, Daniela Albuja-Arias, Fernando García-Ávila \\ and M. Raúl Pelaez-Samaniego (D)
}

\author{
Faculty of Chemical Sciences, University of Cuenca, Av. 12 de Abril and Av. Loja, Cuenca 10202, Ecuador; \\ jessica.criollo@ucuenca.edu.ec (J.C.-B.); daniela.albuja@ucuenca.edu.ec (D.A.-A.); \\ fernando.garcia@ucuenca.edu.ec (F.G.-Á.); manuel.pelaez@ucuenca.edu.ec (M.R.P.-S.) \\ * Correspondence: carlos.sancheza@ucuenca.edu.ec; Tel.: +593-991-708-800
}

Citation: Sánchez-Alvarracín, C.; Criollo-Bravo, J.; Albuja-Arias, D.; García-Ávila, F.; Pelaez-Samaniego, M.R. Characterization of Used Lubricant Oil in a Latin-American Medium-Size City and Analysis of Options for Its Regeneration.

Recycling 2021, 6, 10. https:// doi.org/10.3390/recycling6010010

Received: 15 October 2020

Accepted: 12 January 2021

Published: 2 February 2021

Publisher's Note: MDPI stays neutral with regard to jurisdictional claims in published maps and institutional affiliations.

Copyright: (c) 2021 by the authors. Licensee MDPI, Basel, Switzerland. This article is an open access article distributed under the terms and conditions of the Creative Commons Attribution (CC BY) license (https:// creativecommons.org/licenses/by/ $4.0 /)$.

\begin{abstract}
Petroleum-derived products, such as lubricant oils, are non-renewable resources that, after use, must be collected and processed properly to avoid negative environmental impacts. A circular economy of used oils requires the re-refining and reuse of the same. Similar to most countries in Latin America, the management of used oils in Ecuador is still incipient and few cities collect and treat this material properly. In Cuenca, the ETAPA company collects $1344 \mathrm{t} /$ year of used oils, which are subjected to pretreatment operations prior to their use as fuel in a cement factory. However, combustion generates polluting gases and disallows the adding of value to the used oils. The lack of studies on the characterization and methods utilized for recovering used oils under the conditions found in medium-size Latin-American cities (e.g., Cuenca), alongside a lack of government policies, have hindered the adoption of re-refining operations. The objective of this work is to characterize the used lubricant oils in Cuenca, to compare them with the properties of used oils from other countries, and to suggest some re-refining technologies for oils with similar properties. Used oil samples were collected from mechanic shops and car-lubricating shops for characterization. Its physicochemical properties and metal contents are comparable to the used oils in other countries globally. Specifically, the flash point, kinematic viscosity, TBN, and concentrations of $\mathrm{Zn}, \mathrm{Cd}$, and $\mathrm{Mg}$ are similar to the properties of used oils in Iraq, Egypt, and the United Arab Emirates. Based on these results, the best re-refining option for used oils in Cuenca is extraction with solvents in which sedimentation and dehydration (already conducted in Cuenca) is followed by a solvent reaction process, a vacuum distillation process, a finishing process with bentonite, and a final filtration step.
\end{abstract}

Keywords: waste lubricating oil; characterization; used oil management; circular economy

\section{Introduction}

Lubricating oil (or engine lubricant oil), a product derived from petroleum refining, is a mixture of essential oils (either virgin or processed, mineral or synthetic) and additives. Lubricant oils are used in equipment with moving parts to reduce friction and surface wear off [1], which makes these oils widely employed for the operation of internal combustion engines (ICEs; both gasoline- and diesel-type engines). During the operation of ICEs, the additives in the oil are partially consumed and the oil quality decreases over time due to degradation by oxidation, decomposition of oil and its additives, and contamination with water, gasoline (or diesel), dirt, metals, and carbon particles [2]. The degradation of lubricant oil reduces its life, which severely limits its reusability. Thus, it needs to be replaced with new oil [3]. The used lubricant oil must be collected and stored adequately to avoid environmental pollution, such as from spillage. Often, used lubricant oils are burnt without any treatment, which emits harmful gases into the environment. Sometimes these materials are even spilled in rivers [4].

Used lubricating oils contain heavy metals (e.g., $\mathrm{Cr}, \mathrm{Cd}$, As, and $\mathrm{Pb}$ ) and harmful chemical compounds, such as polynuclear aromatic hydrocarbons, benzene, chlorinated 
solvents, polychlorinated biphenyl (PCBs), and polycyclic aromatic hydrocarbons (PAHs). Therefore, proper management of used oils is necessary to avoid the negative effects inflicted on human health and nature [5]. From an environmental point of view, combustion of used oils is not recommended [5], since the improper incineration of $5 \mathrm{~L}$ of used oil could pollute an amount of air equivalent to that needed by a person to live over three years [6]. The adsorption of $\mathrm{Cr}$ and its compounds released by burning used oil can cause some types of cancer [5]. The negative impacts of the improper management of used oil on the environment and on human health [7] require the exploration of options for regenerating these oils with the intent of producing new lubricants and other petroleumderived products. The yield of lubricant oils through the re-refining of used oils is higher than the yield from virgin crude petroleum refining [2], promoting a reduction of about $90 \%$ of the environmental impacts that otherwise could result from the production of petroleumderived lubricant oils [7]. Some companies in the world, particularly large industries that consume lubricants, regenerate used oil in their own facilities by physicochemical processes to remove the contaminants. Then, the regenerated oil is added to new oils to operate ICEs or is used in other industrial applications, such as gear lubricants, cutting oil, and metal-rolling lubricants [8]. This option has the advantage of reducing losses in each processing step, although the regenerated oil cannot be used again in the engines or gearboxes in vehicles due to degradation. Thus, lubricating oils must be re-refined for further use as lubricants in ICEs [9].

Our literature review suggests that there is a limited amount of studies reporting on the collection methods, characterization, and reuse techniques for used lubricating oils in Latin-American countries. Mexico and Brazil are the leading countries in the region on the reuse of used lubricant oils. In Mexico, Bravo Energy recovers around 100 million L of used oil in the form of fuels from Mexico and other countries (the US, Argentina, and Chile) [8]. Brazil consumes around 1 billion L/year of lubricating oil, $60 \%$ of which corresponds to automobile ICEs. More than $36 \%$ of the collected used oil in the country is derived from cars' ICEs [10]. The Sindicato Nacional da Indústria do Rerrefino de Óleos Minerais, "Sindirrefino" [11], ensures that the oil-refining activities in Brazil follow the latest technology, obtaining products duly specified by the National Petroleum Agency, according to Portaria ANP-130/1999. The industrial park has three differentiated technologies: (a) an acid/clay system with a "cracking term", obtaining a neutral heavy base oil; (b) a flash distillation or skin evaporation system, which allows obtaining a light and medium neutral base oil; and (c) an extraction system selective of propane solvents to obtain a medium neutral base oil. Currently, there are several Latin-American cities that possess private re-refining plants. Some examples of re-refining plants include CILCA (Lima, Peru) [12], Biofactor (Duran, Ecuador) [13], Nueva Energía S.A. (Buenos Aires, Argentina) [14], and other plants in Medellin and Bogota (Colombia) [15]. In September 2019, the IDB (Inter-American Development Bank) approved a loan to co-finance an oil recovery plant in Central America in partnership with the Costa Rican company Metalub, which currently collects and ships used oils to the US for re-refinement [16]. However, in the region, re-refining is mostly solely conducted at the city scale; thus, countries as a whole are not involved in the efficient collection and re-refining systems of used oils.

In Ecuador, the State, through the Agency of Regulation and Control of Hydrocarbon Fuels (ARCH) [1], regulates and controls all activities related to the production, distribution, and use of petroleum and petroleum-derived fuels and lubricants. According to the Central Bank of Ecuador, from January to July 2018, the country imported 70,081 $\mathrm{t}$ of lubricants, corresponding to an FOB value above US\$ 100 million [17]. In May 2019, the Ministry of the Environment of Ecuador (Ministerio del Ambiente) promulgated Law 042 to regulate the management of used lubricant oils and the containers of these materials; it establishes general guidelines on the storage, collection, and final disposal of used lubricating oils, and the minimum collection goal corresponds to $20 \%$ calculated on the total tons of lubricating oil imported or manufactured annually [18]. However, the law does not make specific reuse operations or the re-refining of used oils mandatory. According to data from Arc 
\& Pieper S.A. (from Quito), around 84 million L/year of used oils are not recovered in the country. From it, 30\% correspond to automotive and industrial used oils [19]. Few municipal governments (i.e., Cuenca, Ambato, Quito, Ibarra, and El Coca) and the Provincial Government of Tungurahua have protocols to collect and recycle used oils. In Quito, the BIOfactor company [13] collects all types of oils generated by the city and neighboring cities in the north of Ecuador. The company has a re-refining capacity of 9 million L/year (in the city of Duran), which corresponds to approximately $11 \%$ of the oil used in the country. Nevertheless, only the municipal government of Cuenca has an environmental license from the Ministry of Environment (MAE) to collect and treat used oils [19]. This city (a medium-size Latin-American city, with less than half a million inhabitants), through the ETAPA company (Municipal Company of Telecommunications, Potable Water, and Sewerage), has been carrying out a program called "Collection of Used Batteries and Used Oils" since 1998, aiming to generate environmental awareness among the population and promoting an adequate management of these wastes [20].

Currently, ETAPA collects 151,200 L/month ( 1534 t/year) of used oil from "used oil generators", a group of approximately 1300 car-lubricating shops, mechanic shops, car wash shops, and tire repair shops, and some miscellaneous industrial companies in Cuenca. This amount of used oil collected is approximately $57 \%$ of the total consumed in the city [20]. The remaining is sold to an informal market that employs this oil as fuel in furnaces for bricks, tile manufactures, and, less frequently, for wood treatment, concrete formwork, spraying of cars' bottoms after car-washing, as a pesticide, to reduce dust on unpaved roads, or to protect cattle from subcutaneous parasites [19]. The practice of employing used oils as fuel is common in Latin-American countries (see, for example, [21]). Evidently, some of these uses are not environmentally friendly. It is expected that, in Ecuador, Law 042 could promote better management practices of used oils and reduce pollution.

The oil collected by ETAPA is subsequently treated in its own waste treatment facility through decantation, filtration, and clarification processes to separate the water and solid impurities. Following the Ecuadorian Technical Standard NTE-INEN 2266: 2017 for the transport, storage, and handling of hazardous materials, the treated oil is sent to a cement company in Guayaquil where it is burnt as fuel [20]. However, the management system of used oils in the city requires expenses that currently are paid by both the municipal government and the used oil generators. The sale of used oils to an informal market could be explained in part by the propensity of used oil generators to reduce such additional costs. Thus, adding value to used oils could help to reduce its utilization in informal markets. Despite these problems, the collection and treatment system have been effective at avoiding spillages and harmful discharges of used oil.

The implementation of Law 042 [18] would boost the required steps towards a circular economy that prioritizes regeneration and reuse of used lubricant oil. For this purpose, a deep understanding of the properties of used oil and the potential options for adding value to this material are critical [22]. In the case of Ecuador, information on the properties of used oils is scarce. Almeida et al. [4] characterized some properties of used oils in Quito. In Cuenca, Jaramillo et al. [23] characterized two types of oils commonly used in taxis (SAE 20W50 and SAE 10W30) to determine the most common causes of engine wear. Likewise, ETAPA has determined some properties of the used oils they collect (mixtures of automotive and industrial used oils) [24]. However, there are no current works showing a complete characterization of used oils or suggestions about possible routes for re-refining these materials as part of a circular economy strategy in the conditions of Cuenca and other cities in Ecuador. The objective of this work was twofold: (a) to characterize the used lubricant oils collected in Cuenca and compare the resulting properties with those of used oils elsewhere; and (b) to recommend regeneration options for used oils, considering the characteristics of the oils and the experiences reported in other places. The work hypothesizes that, if the characteristics of used oils in Cuenca are comparable to those in other places where used oil management is adequately performed, it is possible to adapt such proven processes to the conditions of our city. This paper summarizes the main 
findings of the research and expects to contribute with ideas for a better management of used lubricating oils in medium- (e.g., Cuenca) and small-size cities.

Figure 1 summarizes the process to be developed in this research in order to meet the proposed objective.

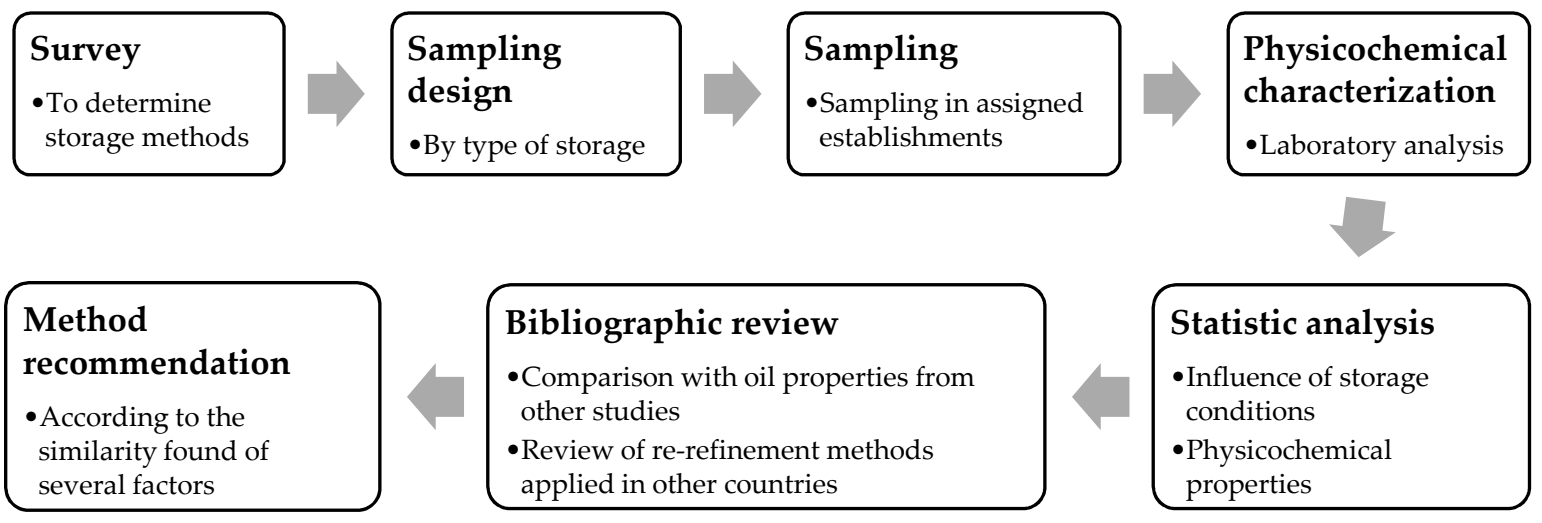

Figure 1. Process for the development of this research.

\section{Materials and Methods}

\subsection{Materials}

Samples of used lubricant oils were obtained from mechanic car shops and other used oil generators in the city of Cuenca. A preliminary step consisted of surveying a group of 265 randomly selected (out of the 1300) used oil generators registered by ETAPA to identify the collection methods and storage conditions of the used oils [25]. Based on the preliminary results, it was determined that the number of storage containers in the city is 16 , for which a sample was taken from each one and the four most frequently repeated were duplicated, taken from different establishments (Samples 4 and 7, 5 and 6, 8 and 9, 14 and 15). The collection of three extra samples directly from the engines of three gasoline vehicles (i.e., used oil without being mixed or exposed to contamination from external agents) also was conducted for a comparison of the properties. Therefore, twenty-three oil samples were collected in total. The twenty samples were mixtures of various types of used automotive oils (mostly engine and gearbox lubricant oils) that have been stored under different conditions (e.g., using plastic or metallic containers), as presented in Table 1. As seen in the table, in Cuenca, the used oils are stored in the used oil generators' facilities for up to three months prior to collection by ETAPA. Samples of $\sim 500 \mathrm{~mL}$ were extracted directly from the storage tanks. The collected samples were then sent to the Chemical Control Laboratory of the Guangopolo Power Plant (Termopichincha Unit-CELEC EP) for characterization.

\subsection{Characterization of the Used Oil Mixtures}

The twenty three samples were characterized with the purpose of determining the water content, density at $15{ }^{\circ} \mathrm{C}$, viscosity index, base number, flash point, kinematic viscosity at $100^{\circ} \mathrm{C}$, and metals content (Al, Ba, B, Cd, Ca, Cu, Cr, Sn, P, Fe, Mg, Mn, Mo, Ni, $\mathrm{Ag}, \mathrm{Pb}, \mathrm{Si}, \mathrm{Na}, \mathrm{Ti}, \mathrm{V}$, and $\mathrm{Zn}$ ). Water content was determined following ASTM D95 [26]. Density was determined as per ASTM D4052-11 [27]. The viscosity index was calculated from the kinematic viscosity at 40 and $100{ }^{\circ} \mathrm{C}$ and following the ASTM D 2270-93 procedure. The base number (TBN) was obtained by potentiometric titration, following ASTM D289611 Procedure B [28]. The flashpoint was obtained in accordance with ASTM D92-12b [29]; i.e., using the Cleveland open cup method. The thermal bath method (ASTM D445-15 Procedure A) [30] was used for the kinematic viscosity index at $100{ }^{\circ} \mathrm{C}$. The metal content was determined in accordance with ASTM 6595-00 (2011) [31]. All tests were conducted in 
duplicate. Table 2 show the analytical instruments' specifications for the characterization of the used oil mixtures.

Table 1. Storage conditions of the used oils in mechanics and car lubricating shops in Cuenca.

\begin{tabular}{cccccc}
\hline $\begin{array}{c}\text { Sample } \\
\text { Number }\end{array}$ & $\begin{array}{c}\text { Container } \\
\text { Material }\end{array}$ & $\begin{array}{c}\text { Top of } \\
\text { Tank }\end{array}$ & $\begin{array}{c}\text { Pre-Filtered } \\
\mathbf{a}\end{array}$ & Covered $^{\mathbf{b}}$ & $\begin{array}{c}\text { Collection } \\
\text { Frequency } \mathbf{c}^{\mathbf{c}}\end{array}$ \\
\hline 1 & Directly from vehicle's engine & no & - & - \\
2 & Directly from vehicle's engine & no & - & - \\
3 & Directly from vehicle's engine & no & - & - \\
4 & Metal & Closed & no & yes & monthly \\
5 & Metal & Closed & no & yes & monthly \\
6 & Metal & Closed & no & yes & monthly \\
7 & Metal & Closed & no & yes & monthly \\
8 & Metal & Closed & no & yes & bimonthly \\
9 & Metal & Closed & no & yes & bimonthly \\
10 & Metal & Closed & no & yes & quarterly \\
11 & Metal & Closed & no & no & monthly \\
12 & Metal & Closed & yes & no & monthly \\
13 & Metal & closed & yes & yes & bimonthly \\
14 & Metal & closed & yes & yes & monthly \\
15 & Metal & closed & yes & yes & monthly \\
16 & Metal & open & yes & yes & monthly \\
17 & Metal & open & no & yes & monthly \\
18 & HDPE & closed & no & no & monthly \\
19 & HDPE & closed & no & yes & bimonthly \\
20 & HDPE & closed & no & yes & quarterly \\
21 & HDPE & closed & yes & yes & quarterly \\
22 & HDPE & closed & yes & yes & monthly \\
23 & HDPE & open & yes & yes & monthly \\
\hline
\end{tabular}

a Refers to a screening process to remove large particles (e.g., wipe cloth) prior to storing in the tanks. ${ }^{\text {b }}$ Indicates if the storage container has been under roof conditions or not. ${ }^{c}$ Frequency of collection of the used oils from the used oil generators' facilities.

Table 2. The analytical instruments' specifications.

\begin{tabular}{|c|c|c|c|c|}
\hline Parameter & A. Instrument & Brand & Model & Serial Number \\
\hline Water content & Distiller & Stanhope Seta & $24415-2$ & 1031631 \\
\hline Density at $15^{\circ} \mathrm{C}$ & $\begin{array}{c}\text { Digital } \\
\text { densimeter }\end{array}$ & Mettler Toledo & Densito $30 \mathrm{PX}$ & LWE13A54 \\
\hline Viscosity index & $\begin{array}{c}\text { Thermostatic } \\
\text { bath }\end{array}$ & Petrotest & Visco Bath & 0263125001 \\
\hline $\begin{array}{c}\text { Total base } \\
\text { number (TBN) }\end{array}$ & Potentiometer & Metrohm & 916 Ti Touch & 1916001003195 \\
\hline Flashpoint & $\begin{array}{l}\text { Equipment to } \\
\text { flashpoint }\end{array}$ & Fisher Tag & Flash Tester & 926 \\
\hline Metal content & $\begin{array}{l}\text { Atomic emission } \\
\text { spectrometer }\end{array}$ & Spectroil & M/F-W & 626 \\
\hline
\end{tabular}

\subsection{Statistical Analysis of the Used Oil Properties}

The results obtained were statistically analyzed in three steps: The first step focused on identifying the similarities among the 23 oil samples, from a physicochemical perspective. For this purpose, a cluster analysis using the SPSS program was conducted and the samples with similar characteristics were grouped [32]. Then the agglomeration method (i.e., a hierarchical classification in which algorithms are used to group objects, using a measure of Euclidean squared distance between data and the Ward linkage that measures remoteness between groups) was employed. According to [32], this method is used to analyze quantitative variables when the sample size is relatively small $(<50)$. With this analysis, a classification tree or dendrogram was prepared (see Figure 2). Since small distances 
indicate homogeneous conglomerates and large distances show diversified conglomerates, it is convenient to stop the grouping process when the horizontal lines become long [32]; this procedure determines the number of clusters. In the second step of the analysis, the inference statistical technique "confidence interval" (with a 95\% level of confidence) was employed [33]. In the third step, a comparison of the physicochemical characteristics of the used oils in Cuenca to the properties of used oils in other countries was conducted. Box and whisker plots were employed to summarize the data and to identify outliers (using the SPSS software).

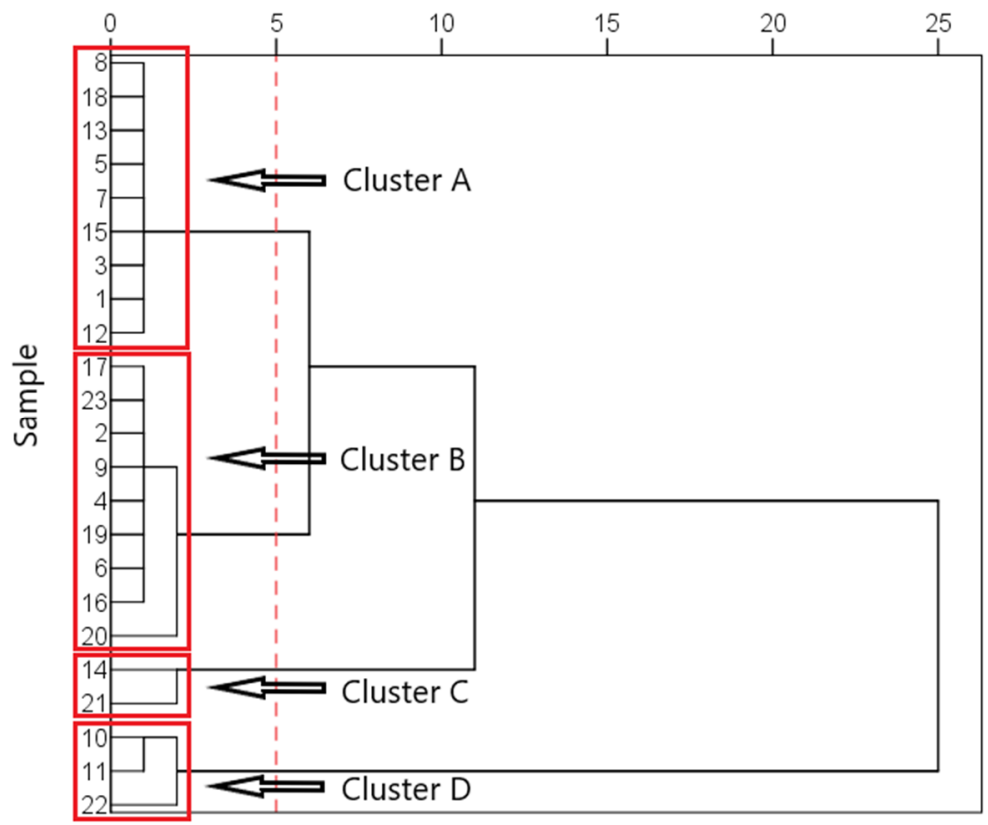

Figure 2. Cluster analysis of the physicochemical properties of the mixtures of used oils (a dendrogram using the Ward link).

\subsection{Analysis of Options for Re-Refining Used Oils in Cuenca}

The results of the characterization and experiences reported in the literature served to propose options of technologies that could be employed to re-refine used oils in Cuenca. This stage sought to establish the requirements that could enable the processing and utilization of used oils as part of the circular economy strategy in the city. The options that were analyzed considered five factors: (1) the amount of available used oil collected in the city alongside the possibility of expanding used oil collection in neighboring cities; (2) the quality of the used oil; (3) the yield of byproducts that can be obtained from used lubricant oils through re-refining, based on the literature and the limitations of some re-refining technologies; (4) the availability of materials for the treatment process close to the city; and (5) the costs of the regeneration technologies and the possible uses of the waste.

\section{Results and Discussion}

\subsection{Physical Characteristics of the Used Oils, and Their Metal Content, in Cuenca}

The initial test of normality of the properties of the used oils in Cuenca showed that the physical properties, such as water content, density, viscosity index, kinematic viscosity, and the presence of elements ( $\mathrm{Al}, \mathrm{B}, \mathrm{Cd}, \mathrm{Cr}, \mathrm{Fe}, \mathrm{Mg}, \mathrm{Mn}, \mathrm{Mo}, \mathrm{Ni}, \mathrm{Ag}, \mathrm{Na}, \mathrm{Ti}$, and $\mathrm{V}$ ), present a normal behavior. Thus, the central tendency measure is the mean. However, the TBN and the concentrations of $\mathrm{Ba}, \mathrm{Ca}, \mathrm{Cu}, \mathrm{Sn}, \mathrm{P}, \mathrm{Pb}, \mathrm{Si}$, and $\mathrm{Zn}$ in the used oil did not show a normal distribution. Therefore, for these properties, we performed a data transformation through the Cox-Box method, using Minitab 19 software. After these considerations, the ranges of the values for each physical property and the metal content are shown in Table 3. 
Table 3. Physical properties and metal content of the used oils in Cuenca city.

\begin{tabular}{|c|c|c|c|}
\hline Parameter & Unit & Mean & Range $^{a}$ \\
\hline Water content & $\% v / v$ & 0.2 & $0.1-0.3$ \\
\hline Density at $15^{\circ} \mathrm{C}$ & $\mathrm{g} / \mathrm{mL}$ & 0.88 & $0.88-0.89$ \\
\hline Viscosity index & - & 132.6 & $128.1-137$ \\
\hline Total Base number (TBN) & $\mathrm{mg} \mathrm{KOH} / \mathrm{g}$ & 5.8 & $4.8-6.8$ \\
\hline Flashpoint & ${ }^{\circ} \mathrm{C}$ & 179.5 & 168-191 \\
\hline Kinematic viscosity at $100{ }^{\circ} \mathrm{C}$ & $\mathrm{mm}^{2} / \mathrm{s}$ & 12.2 & $11-13.4$ \\
\hline $\mathrm{Al}$ & $\mathrm{mg} / \mathrm{kg}$ & 8 & $6.1-9.8$ \\
\hline $\mathrm{Ba}$ & $\mathrm{mg} / \mathrm{kg}$ & 1.5 & $0.3-2$ \\
\hline B & $\mathrm{mg} / \mathrm{kg}$ & 43 & $24.8-62$ \\
\hline $\mathrm{Cd}$ & $\mathrm{mg} / \mathrm{kg}$ & 0.4 & $0.02-0.2$ \\
\hline $\mathrm{Ca}$ & $\mathrm{mg} / \mathrm{kg}$ & 1988.7 & $1744.4-2233.1$ \\
\hline $\mathrm{Cu}$ & $\mathrm{mg} / \mathrm{kg}$ & 13.4 & 2.8-23.9 \\
\hline $\mathrm{Cr}$ & $\mathrm{mg} / \mathrm{kg}$ & 2.9 & $1.5-4.1$ \\
\hline Sn & $\mathrm{mg} / \mathrm{kg}$ & 9.2 & $0.5-2.9$ \\
\hline $\mathrm{P}$ & $\mathrm{mg} / \mathrm{kg}$ & 910.5 & $782.2-1038.7$ \\
\hline $\mathrm{Fe}$ & $\mathrm{mg} / \mathrm{kg}$ & 40.6 & 21.3-59.8 \\
\hline $\mathrm{Mg}$ & $\mathrm{mg} / \mathrm{kg}$ & 37.8 & $14.3-61.2$ \\
\hline Mn & $\mathrm{mg} / \mathrm{kg}$ & 3.2 & $2.2-4.2$ \\
\hline Mo & $\mathrm{mg} / \mathrm{kg}$ & 31 & $15.5-46.4$ \\
\hline $\mathrm{Ni}$ & $\mathrm{mg} / \mathrm{kg}$ & 1.8 & 1.1-2.6 \\
\hline $\mathrm{Ag}$ & $\mathrm{mg} / \mathrm{kg}$ & 0.7 & $0.1-0.5$ \\
\hline $\mathrm{Pb}$ & $\mathrm{mg} / \mathrm{kg}$ & 39.6 & $1.3-25.4$ \\
\hline $\mathrm{Si}$ & $\mathrm{mg} / \mathrm{kg}$ & 20.2 & $13.9-26.4$ \\
\hline $\mathrm{Na}$ & $\mathrm{mg} / \mathrm{kg}$ & 62.7 & 24-101.4 \\
\hline $\mathrm{Ti}$ & $\mathrm{mg} / \mathrm{kg}$ & 12 & $3.1-15.7$ \\
\hline $\mathrm{V}$ & $\mathrm{mg} / \mathrm{kg}$ & 3.3 & $1.7-5$ \\
\hline $\mathrm{Zn}$ & $\mathrm{mg} / \mathrm{kg}$ & 781 & $671-890.1$ \\
\hline
\end{tabular}

a $95 \%$ level of confidence.

\subsection{Influence of Storage Conditions on Used Oil Properties}

The result of the cluster analysis of the physicochemical properties of the twenty-three samples is presented in Figure 2. For the analysis, Euclidean squared distance and Ward's linkage were chosen to create homogeneous groups [32]. In the dendrogram (Figure 2), a distance of 5 was chosen, obtaining four clusters (according to the similarity of their physicochemical properties) called Clusters A, B, C, and D. Cluster A contains nine samples (i.e., Samples 8, 18, 13, 5, 7, 15, 3, 1, and 12), Cluster B also consists of nine samples (i.e., Samples 17, 23, 2, 9, 4, 19, 6, 16, and 20), Cluster C consists of two samples (i.e., Samples 14 and 21), and Cluster D consists of three samples (i.e., samples 10, 11, and 22). Sample 2 , as seen in Figure 2, corresponds to the average values of the properties of the 23 oil samples. The corresponding properties moved away as the Euclidean distances of the other samples moved too. An ANOVA test was performed to compare the means of the groups (at the $95 \%$ confidence level). Figure 2 suggests that the storage conditions are not grouped but are different within the same cluster. Samples 1, 2, and 3, which were taken directly from vehicles' engines (Table 1), are located within Clusters A and B, with characteristics similar to the other stored samples, suggesting that the storage time (i.e., up to three months) does not affect the properties of the used oils. Clusters C and D, despite having fewer samples, also show different storage conditions. Therefore, this finding indicates that there is no correlation between the storage conditions (i.e., type of material of the containers and time) and the oil's characteristics. This can be confirmed because the properties of the oils extracted directly from the vehicle engines, which correspond to the zero storage date, were analyzed under the same environmental conditions as the other stored samples. Furthermore, due to the climatic conditions of Cuenca (which is more or less constant throughout the year), there are no temperature variations that could compromise the properties of the oil during storage. 


\subsection{Physical Properties of the Used Lubricating Oils in Cuenca and Comparison with the Properties of the Used Oils in Various Countries}

Table 4 shows the values of the physical properties and metal content of the used oils in Cuenca (Column 2) and the new lubricant oils that are employed in the city (Column 3). The table also presents the typical values and expected limits of both the physical properties and metal contents reported in the literature, as well as the expected tendencies of each property or value compared to the new oils. It can be seen that, for used oils in Cuenca, most values are below the accepted limits, according to [34]. Moreover, the water content is below the limits reported by [34] and the rest of the results (except the concentration of some metals) are in the range of expected values $[8,35]$. This result suggests that the re-refining options for used oils in Cuenca should take advantage of the experiences in other places that process used oils with similar properties to guarantee the properties of the regenerated oil as required for further use.

Table 4. The physical properties and metal concentration of the used lubricant oils in Cuenca, in comparison with other oils.

\begin{tabular}{|c|c|c|c|c|c|c|}
\hline \multirow[b]{2}{*}{ Property } & \multicolumn{2}{|c|}{ Oils in Cuenca } & \multicolumn{2}{|c|}{ Typical Range Other Studies } & \multirow{2}{*}{$\begin{array}{c}\text { Expected } \\
\text { Limits [34] }\end{array}$} & \multirow{2}{*}{$\begin{array}{l}\text { Tendency with } \\
\text { Respect to } \\
\text { New Oils }\end{array}$} \\
\hline & This Study & $\begin{array}{l}\text { Average New } \\
\text { Oils [23] }\end{array}$ & Ref. [8] & Ref. [35] & & \\
\hline Water content $(\% v / v)$ & 0.2 & 0.1 & - & $1.1-13.7$ & - & increases \\
\hline Flashpoint $\left({ }^{\circ} \mathrm{C}\right)$ & 178.1 & - & $75-240$ & $120-214$ & $>38$ & decreases \\
\hline $\begin{array}{c}\text { Density at } 15^{\circ} \mathrm{C} \\
(\mathrm{g} / \mathrm{mL})\end{array}$ & 0.9 & - & - & - & - & increases \\
\hline Viscosity index & 134.2 & 138.1 & - & $92.5-144$ & - & increases \\
\hline TBN (mg KOH/g) & 5.7 & 5.3 & - & $4.1-4.7$ & - & decreases \\
\hline $\begin{array}{l}\text { Kinematic Viscosity } \\
100{ }^{\circ} \mathrm{C}\left(\mathrm{mm}^{2} / \mathrm{s}\right)\end{array}$ & 11.8 & 16.4 & - & $9.3-14.8$ & - & increases \\
\hline \multicolumn{7}{|c|}{ Metals content (mg/kg) } \\
\hline $\mathrm{Al}$ & 8 & $<1$ & - & $4-20.3$ & $<20$ & increases \\
\hline $\mathrm{Ba}$ & 1.5 & 64.7 & $5-110$ & - & - & decreases \\
\hline $\mathrm{B}$ & 43 & 10 & - & $30-4100$ & - & decreases \\
\hline $\mathrm{Cd}$ & 0.4 & - & 0-3.8 & 2-9.4 & $<2$ & increases \\
\hline $\mathrm{Ca}$ & 1988.7 & 1396.6 & 936-1670 & $606-1890$ & - & decreases \\
\hline $\mathrm{Cu}$ & 13.4 & $<1$ & - & $7-30$ & $<30$ & increases \\
\hline $\mathrm{Cr}$ & 2.9 & $<1$ & - & $3.2-233$ & $<10$ & increases \\
\hline Sn & 9.2 & $<1$ & - & 9.7 & $<20$ & increases \\
\hline $\mathrm{P}$ & 910.5 & 802.2 & 494-973 & - & - & decreases \\
\hline $\mathrm{Fe}$ & 40.6 & 1.3 & 23-99 & 15-348 & $<100$ & increases \\
\hline $\mathrm{Mg}$ & 37.8 & 12 & $66-120$ & $43.5-332$ & - & decreases \\
\hline $\mathrm{Mn}$ & 3.2 & - & $0.9-18$ & - & - & increases \\
\hline Mo & 31 & 97.9 & $24-42$ & - & - & decreases \\
\hline $\mathrm{Ni}$ & 1.8 & $<1$ & $0-5.4$ & 2 & $<10$ & increases \\
\hline $\mathrm{Ag}$ & 0.7 & $<1$ & - & - & $<3$ & increases \\
\hline $\mathrm{Pb}$ & 39.6 & $<1$ & $7-57$ & $2-2813$ & $<30$ & increases \\
\hline $\mathrm{Si}$ & 20.2 & 4.3 & $29-76$ & $11-21.9$ & $<20$ & increases \\
\hline $\mathrm{Na}$ & 62.7 & 48.1 & $174-606$ & 13-65 & $<50$ & increases \\
\hline $\mathrm{Ti}$ & 12 & $<1$ & $0-4.9$ & - & - & increases \\
\hline $\mathrm{V}$ & 3.3 & $<1$ & $0.2-10$ & - & - & increases \\
\hline $\mathrm{Zn}$ & 781 & 803.3 & $444-1280$ & 54.9-1100 & - & decreases \\
\hline
\end{tabular}

Table 5 shows a comparison of the physical properties, presence of metals, and concentration of additives of the used oils in Cuenca with those of used oils in other countries. Some properties are difficult to compare due to a lack of data. However, it is seen that, as with other materials, the water content is below the values reported in other countries. Properties such as viscosity are of interest since they show that the oils have not degraded too much during their use, as well as indicating a lower water content. 
Metals such as $\mathrm{Al}, \mathrm{Cd}, \mathrm{Cr}, \mathrm{Cu}, \mathrm{Fe}, \mathrm{Pb}, \mathrm{Mn}, \mathrm{Mg}, \mathrm{Ni}, \mathrm{Ag}$, $\mathrm{Sn}, \mathrm{Ti}$, and V (Table 6), known as wear metals [8], arise in the used oil due to the engines' high operating temperatures and pressures. Thus, the concentrations of metals found in the used oil vary depending on the brand and the type of used oil, the conditions of the engine that originated them, and the distance traveled by the vehicle until oil change is performed [36]. Ti is outside the range of typical values for used oils with a much higher value. Oil liquid Ti is widely used to reduce the friction and wear of engine components [37], which could explain such high values for Ti content. In the case of engine wear metals, all values are below the mean of the countries reported in the literature (except for $\mathrm{S}$ and $\mathrm{V}$, from which there are not enough results to compare in Table 5); however, they are below the typical ranges as reported by Parry [8] and Widodo et al. [35], as seen in Table 4. The results indicate that the oils have a low contamination by wear metals, especially in the case of $\mathrm{Si}, \mathrm{Al}, \mathrm{Cu}, \mathrm{Cr}$, and Fe. Si is considered a highly abrasive material [38]. Its presence in the used oil is mainly due to contamination by sediments or some brake fluids, as well as by dust (dirt) entering the engine. The concentration of additives such as $\mathrm{Ba}, \mathrm{B}, \mathrm{Ca}, \mathrm{Mg}, \mathrm{Mo}, \mathrm{Na}, \mathrm{P}$, and $\mathrm{Zn}$ (Table 7) is reduced with respect their initial concentrations. $\mathrm{P}$ and $\mathrm{Zn}$ are elements that are generally found in anti-wear additives and antioxidants used to protect metal segments under engines' extreme operating conditions. $\mathrm{Ca}, \mathrm{Mg}$, and $\mathrm{Na}$ sulfonate are mainly associated with the detergents/dispersants used for engine cleaning. Some engine oils contain MoS2 to reduce wear at high temperatures and pressures. B and Ba are used in some synthetic oil formulations and act as anti-wear additives [22,36,39]. Regarding B, there are not enough data to compare with other countries (Table 5), but it is within a typical range according to Widodo. et al. as seen in Table 4. Some metals that are components of the engines also serve as additives in lubricating oils. This is the case of $\mathrm{Al}, \mathrm{Cu}, \mathrm{Mg}$, $\mathrm{Ti}$, and Mo. If the concentration of an element in the used oil increases with respect to the concentration of the virgin oil, it is considered a wear metal, otherwise it is considered an additive. Ba and $\mathrm{Mg}$ content is below the mean of the typical values reported in the literature (Table 7), which suggests that part of these elements was lost during the operation of the engines. The $\mathrm{Mo}, \mathrm{Na}, \mathrm{P}$, and $\mathrm{Zn}$ concentrations are also below the mean values (right column), suggesting loss of these metals, but they are still within the typical ranges (see Table 4). Ca has a higher value than the expected values [8,9]. Its content depends on the types or brands of oils present in the mixture.

In general, it is observed that the characteristics of the oils used in Cuenca are within the ranges of values obtained from other countries. The results of this research are close to those reported for used oils in other countries in South America (e.g., Colombia, Chile, and Venezuela), except for the higher water content of the used oils in Chile. This could possibly result from similar climatic conditions, age of the car fleet, and types of oils consumed. Likewise, in Peru, a higher presence of wear metals in used oils is seen, although those used oils retain more additives. The literature also shows that, in Australia, used oils are less contaminated by wear metals, but there is greater loss of additives. Works conducted in the US on the concentration of metals in used oils show values close to used oils in Cuenca. In the case of Spain and Portugal, there is less metal contamination in the used oil, except for Fe. Iraq, Nigeria, and Poland present approximately similar results, although those oils appear less contaminated by metals. The same happens in the case of used oils in the UAE, except for the high content of $\mathrm{Pb}$. The physical characteristics of the used oils in Egypt, Pakistan, and Saudi Arabia show some similarities to the used oils analyzed in this work. However, the metals content cannot be compared due to a lack of information. A high water content and low viscosity index is evident in South Africa's used oil. Kazakhstan, Ukraine, and Ghana show the highest metal-contaminated automotive used oil. 


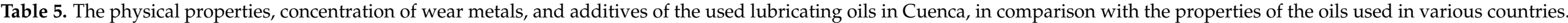

\begin{tabular}{|c|c|c|c|c|c|c|c|c|c|c|c|c|c|c|c|c|c|c|c|c|c|c|c|}
\hline $\begin{array}{l}\text { Element } \\
\text { (ppm) }\end{array}$ & $\begin{array}{l}\text { This } \\
\text { Work }\end{array}$ & $\begin{array}{c}\text { Quito- } \\
\text { Ecuador } \\
{[4]}\end{array}$ & $\begin{array}{l}\text { Chile } \\
\text { [40] }\end{array}$ & $\underset{[5]}{\text { Colombia }}$ & $\begin{array}{c}\text { Venezuela } \\
\text { [41] }\end{array}$ & $\begin{array}{l}\text { Perú } \\
{[42]}\end{array}$ & $\underset{[43]}{\text { Spain }}$ & $\begin{array}{c}\text { Portugal } \\
{[22]}\end{array}$ & $\begin{array}{l}\mathrm{UAE} \\
{[44]}\end{array}$ & $\begin{array}{l}\text { USA } \\
{[45]}\end{array}$ & $\begin{array}{c}\text { Kazakhstan } \\
{[46]}\end{array}$ & $\begin{array}{c}\text { Ghana } \\
{[2]}\end{array}$ & $\begin{array}{c}\text { Nigeria } \\
{[47]}\end{array}$ & $\begin{array}{c}\text { South } \\
\text { Africa } \\
\text { [48] }\end{array}$ & $\begin{array}{c}\text { Ukraine } \\
{[49]}\end{array}$ & $\begin{array}{c}\text { Australia } \\
{[50]}\end{array}$ & $\begin{array}{c}\text { Poland } \\
{[51]}\end{array}$ & $\begin{array}{l}\text { Iraq } \\
{[52]}\end{array}$ & $\begin{array}{l}\text { Iraq } \\
{[53]}\end{array}$ & $\underset{[54]}{\text { Pakistan }}$ & $\begin{array}{c}\text { Saudi } \\
\text { Arabia } \\
\text { [55] }\end{array}$ & $\begin{array}{l}\text { Egypt } \\
\text { [56] }\end{array}$ & Mean \\
\hline $\mathrm{Al}$ & 8 & - & - & 17 & - & 375 & - & - & 4 & - & 57.9 & - & - & 20.1 & - & 64 & - & - & - & - & - & - & 89.7 \\
\hline $\mathrm{Ba}$ & 1.5 & - & - & - & 113 & 9 & 297 & - & $<1$ & 2.9 & - & - & - & - & - & - & - & - & - & - & - & - & 84.6 \\
\hline B & $\begin{array}{l}43 \\
04\end{array}$ & - & $0 \overline{1}$ & - & - & - & - & - & 3 & - & - & - & - & - & - & - & - & 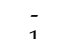 & - & - & - & - & 3 \\
\hline $\begin{array}{l}\mathrm{Cd} \\
\mathrm{Ca}\end{array}$ & $\begin{array}{l}0.4 \\
1988.7\end{array}$ & - & 0.1 & 285.3 & 190 & 1250 & $\overline{4.5}$ & $\begin{array}{c}- \\
1805\end{array}$ & $\begin{array}{l}<1 \\
1667\end{array}$ & 1.7 & $\begin{array}{r}- \\
171.9\end{array}$ & $60 \overline{6} .5$ & - & $=$ & $\begin{array}{c}- \\
1445.7\end{array}$ & 0.04 & - & 1 & $=$ & $=$ & - & - & $\begin{array}{c}0.8 \\
825.1\end{array}$ \\
\hline $\mathrm{Cu}$ & 13.4 & - & 9.7 & 14.3 & 16 & 15 & 29 & - & 7 & 36 & 37.9 & 21.3 & - & $=$ & 74.1 & 7 & 18 & 4.6 & - & - & - & - & $\begin{array}{l}22.3 \\
22.3\end{array}$ \\
\hline $\mathrm{Cr}$ & 2.9 & - & 5 & - & $<1$ & - & - & - & 4 & 3.3 & 18.3 & - & 1.3 & - & 52.6 & 0.2 & 1.4 & 1.5 & - & - & - & - & 8.9 \\
\hline Sn & 9.2 & - & 5 & - & - & - & $-\overline{0}$ & - & $<1$ & - & - & - & - & - & - & - & - & 1.6 & - & - & - & - & 2.5 \\
\hline $\mathrm{P}$ & 910.5 & - & - & 18.4 & - & 1550 & 931 & 739 & 632 & - & - & - & - & - & 2797.1 & 485 & - & - & - & - & - & - & 1021.8 \\
\hline $\mathrm{Fe}$ & 40.6 & - & - & - & 46 & 240 & 205 & 212 & 15 & - & - & 89.5 & - & 21.3 & 696.4 & 41 & 53.5 & 72 & - & - & - & - & 153.8 \\
\hline $\mathrm{Mg}$ & 37.8 & - & - & - & 1.5 & - & 309 & - & 38 & - & 436.1 & - & & - & 549.8 & 24 & 10 & 81 & - & - & - & - & 205.6 \\
\hline $\mathrm{Mn}$ & 3.2 & - & - & - & - & - & - & - & 1 & - & - & - & 5.3 & - & 8.8 & 1 & 1.8 & 1.5 & - & - & - & - & 3.2 \\
\hline $\begin{array}{l}\mathrm{Mo} \\
\mathrm{Ni}\end{array}$ & 31 & - & is & - & - & - & - & $\overline{5}$ & 7 & - & - & - & 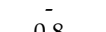 & - & 48.15 & $\therefore$ & 462.9 & - & - & - & - & - & 172.7 \\
\hline $\begin{array}{l}\mathrm{Ni} \\
\mathrm{Ag}\end{array}$ & $\begin{array}{l}1.8 \\
07\end{array}$ & - & 1.4 & - & - & - & - & 5 & $<1$ & 1.5 & - & 2 & 0.8 & - & 5.8 & 0.2 & 0.4 & - & - & - & - & - & 2 \\
\hline $\begin{array}{l}\mathrm{Ag} \\
\mathrm{Pb}\end{array}$ & 39.6 & - & 15.5 & - & - & - & - & & $<1$ & & - & & & - & & & & - & - & - & - & - & $\begin{array}{l}<1 \\
45.4\end{array}$ \\
\hline $\mathrm{Si}$ & 20.2 & - & - & 2.3 & & - & & - & 11 & - & - & & - & $\begin{array}{ll}- \\
-\end{array}$ & 140 & - & - & - & - & - & - & - & 51.1 \\
\hline $\mathrm{Na}$ & 62.7 & - & - & 216.8 & 43.5 & - & 118 & - & 20 & - & - & 9.5 & - & - & - & - & - & - & - & - & - & - & 73.3 \\
\hline $\mathrm{Ti}$ & 12 & - & - & - & - & - & - & - & 2 & - & - & - & - & - & - & - & - & - & - & - & - & - & 2 \\
\hline $\mathrm{V}$ & 3.3 & - & 2 & - & - & - & - & - & $<1$ & - & - & - & - & - & - & - & - & - & - & - & - & - & 1.5 \\
\hline $\mathrm{Zn}$ & 781 & - & $3 \overline{4} 0$ & 825.5 & 651 & 1025 & 1 & 1000 & 780 & 1152 & 403 & - & - & - & 4361 & 254 & 1106.7 & 1280 & - & - & - & - & 1013.8 \\
\hline $\begin{array}{l}\text { Water } \\
\text { con- } \\
\text { tent }\end{array}$ & 0.2 & 0.4 & 10 & 0.5 & 0.6 & 5.1 & - & - & 0.8 & - & 0.03 & - & - & 11.5 & 0.2 & - & - & 0.9 & 1.5 & - & - & 0.3 & 2.7 \\
\hline $\begin{array}{l}\text { Density } \\
\text { at } 15 \\
{ }^{\circ} \mathrm{C}\end{array}$ & 0.9 & - & - & 0.9 & - & - & - & - & 0.9 & - & 0.9 & - & 0.9 & 0.9 & 0.9 & - & - & 0.9 & 0.9 & 0.9 & 0.9 & 0.9 & 0.9 \\
\hline $\begin{array}{l}\text { Viscosity } \\
\text { index } \\
\text { Base }\end{array}$ & 134.2 & 122 & - & - & - & 115 & - & 103.1 & - & - & - & - & - & 25.5 & 110 & - & - & 89.1 & - & 110.6 & 80 & 115.1 & 96.7 \\
\hline $\begin{array}{l}\text { num- } \\
\text { ber } \\
\text { (TBN) }\end{array}$ & 5.7 & 18.6 & - & - & - & - & 1.7 & - & 4.1 & - & - & - & - & - & 3.5 & - & - & 0.1 & 5.8 & 4.6 & 13.5 & - & 6.5 \\
\hline $\begin{array}{l}\text { Flashpoint } \\
\text { Kinematic }\end{array}$ & int178.1 & 90.8 & - & - & 182.2 & - & 348 & - & 152 & - & 190 & - & 135 & 125 & 511 & - & - & 158 & 178 & 183 & 101 & 128 & 190.9 \\
\hline $\begin{array}{l}\text { viscos- } \\
\text { ity at } \\
100^{\circ} \mathrm{C}\end{array}$ & 11.8 & 29.8 & 55 & 81.1 & - & 17 & - & 7.8 & - & - & 9.5 & - & - & 6.5 & 13.9 & - & - & 13.5 & -12 & 15.5 & 14.1 & 12.93 & 22.2 \\
\hline
\end{tabular}




\subsection{Analysis of Options for Re-Refining Used Oils in Cuenca}

The treatment of used lubricant oils involves three processes: recovery, reprocessing, and regeneration (or re-refining) [8]. Reprocessing is carried out by the elimination of contaminants from used oils and may include distillation and chemical treatment, as well as a combination of methods with those used for recovery. With the re-refining process, the highest degree of contaminant removal is reached, obtaining the base oil to manufacture new lubricating oils. Table 6 shows the methods commonly employed for re-refining of used oils at the laboratory scale and Figure 3 summarizes the sequence of these steps. Regardless of the re-refining process, it begins with a pretreatment step that depends on the characteristics of the oil. According to Fong et al. [5], good quality oils can be obtained from used oils and their production costs are relatively lower than the costs of producing oils through petroleum refining. A gallon of used oil $(3.78 \mathrm{~L})$ provides $2.5 \mathrm{~L}$ of lubricating oil, which, otherwise, should require 42 gallons (>158 L) of crude oil [57]. Besides, the byproducts of re-refining can be converted into valued end products for other manufacturing processes, such as asphalt. The yields of the products and byproducts can cover the cost of buying the chemicals needed to keep the operation of the re-refining plant and, therefore, to make the process profitable [5]. An oil of higher quality than the corresponding original oil cannot be obtained using these processes. For this reason, for cost-effective recycling of used oil, it is important to separate the different types of oils in the places used oils are generated because, from the mixture of high-quality and low-quality used oils, only low-quality oils are obtained [8]. Speight and Exall [58] (cited by [35]) indicated that, in the re-refinement process, solid particles and water are separated from the used oil by physical treatments to obtain an oil comparable to the original, but the contaminant metals could not be completely removed.

Table 6. Steps for re-refining used oils and the technologies employed at the laboratory scale.

\begin{tabular}{|c|c|c|}
\hline & Technology & Country and Reference \\
\hline \multirow{5}{*}{ Pre-Treatment } & $\begin{array}{l}\text { Filtration, centrifugation, } \\
\text { decantation, and } \\
\text { sedimentation }\end{array}$ & \multirow[t]{2}{*}{ South Africa [48], Egypt [59] } \\
\hline & Distillation & \\
\hline & Filtration & Egypt [56] \\
\hline & $\begin{array}{l}\text { Sedimentation, magnetization, } \\
\text { heating, and agitation }\end{array}$ & Nigeria [60] \\
\hline & Technology & Country and Reference \\
\hline & Sedimentation & UAE [44] \\
\hline \multirow{7}{*}{ Regeneration } & Acid treatment & $\begin{array}{c}\text { Romania [61], Iran [62], Nigeria [47], } \\
\text { Colombia [5] }\end{array}$ \\
\hline & Caustic treatment & Ghana [2] \\
\hline & $\begin{array}{l}\text { Activated carbon/clay } \\
\text { treatment }\end{array}$ & \multirow{3}{*}{ South Africa [48] } \\
\hline & Distillation/clay & \\
\hline & Acid clay treatment & \\
\hline & $\begin{array}{l}\text { Irradiation and ultrasonic } \\
\text { adsorption }\end{array}$ & Kazakhstan [46] \\
\hline & Solvent extraction & $\begin{array}{c}\text { Egypt [56], Iraq [53], Portugal [22], } \\
\text { Egypt [59], Nigeria [60], Spain [43], } \\
\text { UAE [44] }\end{array}$ \\
\hline
\end{tabular}


Table 6. Cont.

\begin{tabular}{ccc}
\hline \multirow{2}{*}{$\begin{array}{c}\text { Fractionation of the } \\
\text { Bases }\end{array}$} & Vacuum distillation & $\begin{array}{c}\text { Ukraine [49], Egypt [56], Iraq [53], } \\
\text { Ghana [2], UAE [44] }\end{array}$ \\
\cline { 2 - 3 } & $\begin{array}{c}\text { Atmospheric and vacuum } \\
\text { distillations. }\end{array}$ & Spain [43] \\
\hline \multirow{2}{*}{ Finishing } & $\begin{array}{c}\text { Adsorption, neutralization, } \\
\text { sedimentation, and filtration. }\end{array}$ & Romania [61], Nigeria [47] \\
\cline { 2 - 3 } & Filtration and heating & South Africa [48] \\
\cline { 2 - 3 } & Filtration & Colombia [5] \\
\hline Adsorption & $\begin{array}{c}\text { Kazakhstan [46], Egypt [56], Iraq [53], } \\
\text { Nigeria [60], Iran [62], UAE [44] }\end{array}$ \\
\hline
\end{tabular}

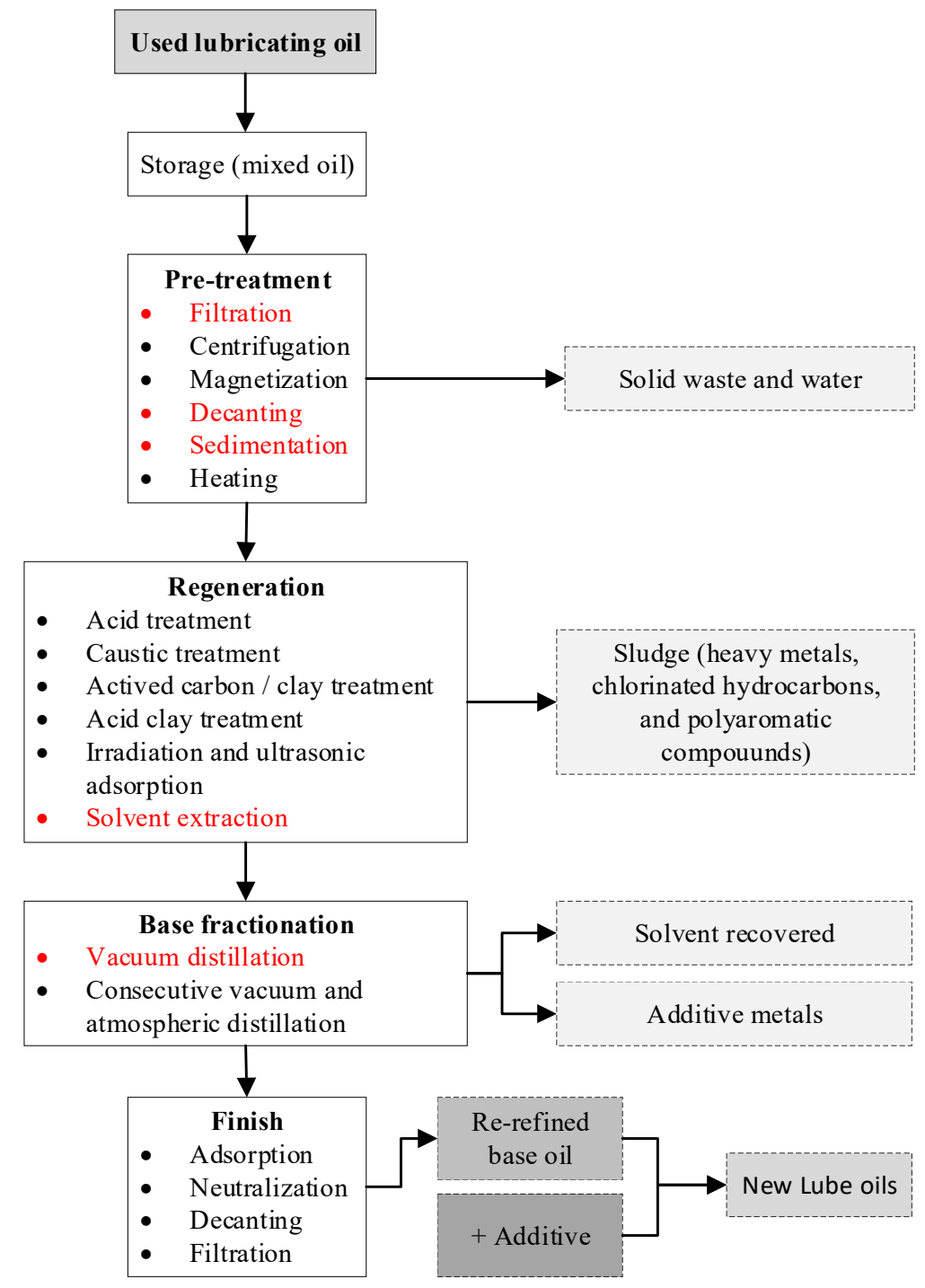

Figure 3. Main stages of conventional technologies for the re-refining of used oils. Adapted from [35].

Re-refining consists of four stages: pre-treatment (i.e., removal of water and solid particles), regeneration (i.e., elimination of degradation products), fractionation of the bases (i.e., separation of light hydrocarbons), and finishing (i.e., improvement of color and smell of the treated oil) $[35,59,63]$. Some of these processes still have some disadvantages, such as the poor performance of oil regeneration or the generation of other environmentally 
hazardous contaminants [35]. Following the logic of the circular economy, the ideal regeneration method for used lubricating oils should guarantee the function the product had at the beginning, as many times as possible after a treatment is conducted.

For the finishing step, excellent results have been obtained with the use of bentonite $[44,50,60,61]$. This is the process that appears most suitable for used oil treatment in Cuenca, due to the large amounts of bentonite available in the province of Napo [64], located $\sim 400 \mathrm{~km}$ from Cuenca. Bentonite can be used as bleaching land to clarify and reduce (by adsorption purification) the intense color of the oils [65]. It is expected that used oil generators (e.g., mechanic and car lubricating shops) in the city will play a vital role in the collection system as they are responsible for the handling, separating, and storing operations for different types of used oils before delivering them to authorized collectors to ensure proper treatment [22].

In Ecuador, in the city of Quito, the re-refining of used lubricating oils is carried out, in this process methods such as filtration, extraction by solvents, and vacuum distillation are applied, while in the city of Cuenca only filtration, decantation, and sedimentation is performed; in Figure 3 these processes are marked in red.

At an industrial scale, the main technologies employed for re-refining used oils are (a) the acid/clay process; (b) activated clay process; (c) thin-film evaporation (TFE), based in vacuum distillation; (d) solvent extraction process; and (e) hydro-treatment process (hydrogen extraction) $[58,65,66]$. The steps for each re-refining technology and the yields that can be recovered from the process are presented in Figure 4.

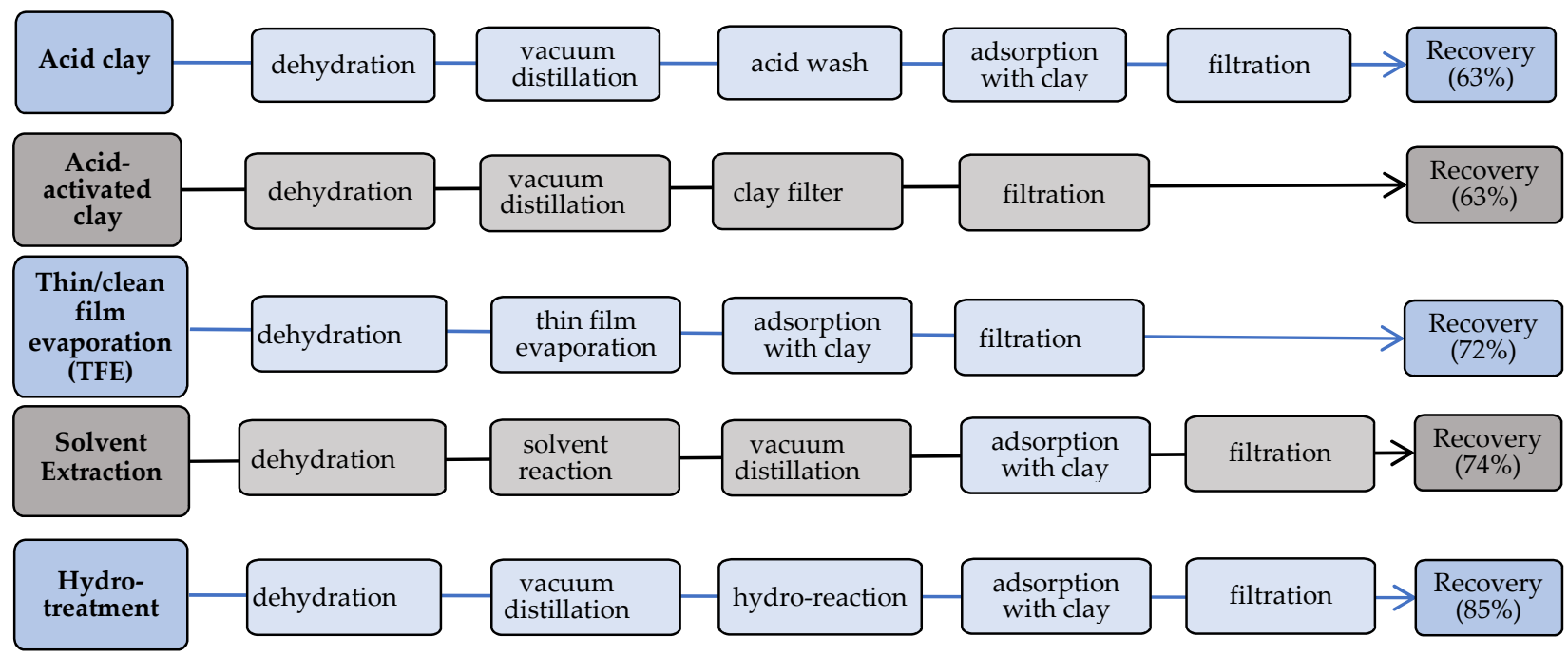

Figure 4. Summary of the technologies employed at the industrial level for re-refining used lubricant oil. Adapted from [66,67]. 
Table 7. The main technologies employed at an industrial scale for re-refining used lubricating oils.

Re-Refining Method
Acid-clay

$[68,69]$

$[68,69]$
Process

Dehydration: removal of impurities, water, antifreeze, and solvents by preliminary distillation at low temperature. Vacuum distillation.

Sulfuric acid: reverse reaction with oxygen, sulfur, and nitrogen to form sludge

Additional refining to eliminate paraffinic and naphthenic hydrocarbons.

Adsorption with clay to reduce odor and dark color.

Dehydration. Vacuum distillation with conventional vacuum column. Adsorption with activated clay at 12 $\mathrm{C}$ for $2 \mathrm{~h}$
Filtered.

\section{Advantages}

Proven technology.

Low production cost.

Simple and straightforward process.

Does not require qualified operators.

Adequate for small capacities.

Low capital investment, profitable for small-scale plants.

Low energy consumption.

Produces good quality base oils.

No acid is required.

Simple process.

Suitable for small capacity plants.

Produces good quality base oils.
Disadvantages

Generates polluting waste. Causes corrosion of equipment.

Low yield due to loss of oil in mud and clay. Not compatible with pollution control regulations.

Technology is prohibited in many countries

High consumption of clay.

Low performance. Inconsistent quality.

Environmental problems to eliminate large amounts of spent clay.

Depends on a particular type of clay that may not be readily available

Suitable for high capacity plants

Dehydration. Evaporation of thin-film (via vacuum distillation). Process involves the removal of volatile materials and the separation of the high boiling distillate from residues containing heavy metals.

Thin film evaporation (TFE) $[59,68]$

Two options: (a) hydraulic finishing to remove chlorine, nitrogen, oxygen, and sulfur compounds or (b)

adsorption with clay to remove impurities (e.g., heavy metals and decomposition products)

Dehydration. Removal of impurities by mixing olvents that do not include sulfuric acid, the solvent produces insoluble and suspended substances (e.g. asphalt, metal compounds, and resin). The sludge removed as non-hazardous waste.

Solvent extraction $[67,68,70]$ Vacuum distillation with conventional vacuum colum. Adsorption with clay to reduce odor and dark color.

Dehydration. Vacuum distillation with conventional vacuum column.

Hydro-treatment [66-68]

The oil treated with hydrogen in the presence of a catalyst removing sulfur, nitrogen, and oxygen. The combination of this process with solvent extraction strengthens the oil quality. Adsorption with clay.
The thin-film evaporator is capable of operating under high vacuum and is usually

used for high value products

It does not cause contamination.

Produces very good quality base oils

The solvent is recyclable.

Does not cause contamination. additives, metals, and tar. It operates at room temperature

Corrects the color and smell of the oil

The distillation process is commonly used to remove sulfur, nitrogen, metals, or unsaturated hydrocarbons
Functional recovery of base oils.

Produces good quality base oils.

Propane is used as a solvent to remove
Operates at high temperature and high vacuum.

The plant must have high capacity to be economically viable.

High energy consumption
Economical only for high plant capacity. Operates at higher pressure.

Requires operating systems and qualified personnel.

May involve operating losses of solvent

Propane can cause fires/explosion. High energy consumption

\section{Expensive.}

Unsafe.

Not suitable at small scale.

High energy consumption.

Operates at high temperature and pressure. 
Details on each technology and the corresponding advantages and disadvantages are presented in Table 7. Other new technologies are currently available, especially in Europe and China, including the combined finishing of TFE and clay, TFE and solvent finishing, TFE and hydro-treatment, thermal deasphalting (TDA), clay finishing, and TDA and hydro-treatment. Kupareva et al. [66] presented an exhaustive review of the technologies employed at the industrial scale for re-refining used oils in Europe and CleanOil in China, as well as a list of the companies/countries using those technologies (see Table 8). Most of those commercial plants use the technologies described above, with small modifications in some cases.

The selection of a specific technology for re-refining used oil at an industrial level involves several criteria $[67,68]$, including (a) technical and sustainability aspects; (b) health, safety, and environmental impacts; and (c) economic considerations. The thinfilm evaporation (TFE) technology appears to offer the best results (in terms of product quality), followed by the solvent extraction, the hydrotreatment, and the activated acid-clay and acid-clay technologies. However, the TFE technology is economically viable only at large scales. The minimum capacity needed for a plant with this technology, according to Kupareva, is around 40,000 t/year (see Table 8), which is several times higher than the $\sim 1534 \mathrm{t} /$ year of used oil collected in Cuenca. Therefore, TFE technology is not currently viable in Cuenca.

The hydrotreatment and the activated acid-clay and acid-clay technologies, however, are incapable of producing products with adequate quality while possibly creating environmental problems [67] (see Table 7). Thus, these technologies are not appropriate compared to the TFE or the solvent extraction technologies. For these reasons, in this study, we believe the solvent extraction technology is the best option for re-refining used oils in Cuenca. The solvent extraction process is more adequate for processing relatively low volumes of used oils and the quality of the product complies with engine requirements. The oil recovery rate is relatively high (around $74 \%$ ) and the process accepts both synthetic and mineral oils used in vehicles [66]. The solvents can be recovered and reused in the process. Moreover, this technology is widely used in other countries [66]. Since the physical properties of the used oils in Cuenca resemble those of countries such as the UAE [44], Iraq [53], and Egypt [56], which recover oils through solvent extraction, the use of this technology is justified and currently feasible. 
Table 8. The main re-refining processes currently used in European countries and China (adapted from [66,71]).

\begin{tabular}{|c|c|c|c|c|c|c|}
\hline Technology & Raw Material & Investment Costs & Product Quality & Yield\% & Waste & Plant Capacity (t/year) \\
\hline \multicolumn{7}{|c|}{ Solvent Extraction } \\
\hline $\begin{array}{c}\text { MRD process } \\
\text { (Germany, Denmark and } \\
\text { the Netherland) }\end{array}$ & $\begin{array}{l}\text { It can contain up to } 5 \% \\
\text { vegetable oils, complete } \\
\text { preservation of synthetic } \\
\text { oils. }\end{array}$ & $\begin{array}{l}\text { Relatively low operating } \\
\text { and capital costs. }\end{array}$ & Base oils of good quality. & 91 & It can use as fuel. & 120,000 \\
\hline $\begin{array}{c}\text { Interline } \\
\text { (Spain and United } \\
\text { Kingdom) }\end{array}$ & $\begin{array}{l}\text { Motor mineral oil and } \\
\text { industrial oils. }\end{array}$ & $\begin{array}{l}\text { Relatively low operating } \\
\text { and capital costs. }\end{array}$ & $\begin{array}{l}\text { Low quality of base oil } \\
\text { (API I). }\end{array}$ & 79 & Asphalt Modifier Production & $\begin{array}{l}\text { Spain: 36,000, United } \\
\text { Kingdom: 50,000 }\end{array}$ \\
\hline $\begin{array}{c}\text { Vaxon } \\
\text { (Denmark and Spain) }\end{array}$ & $\begin{array}{l}\text { Mineral motor and } \\
\text { industrial oils and some } \\
\text { stable synthetics in the } \\
\text { presence of a strong base. }\end{array}$ & Financially attractive. & $\begin{array}{l}\text { The average quality of } \\
\text { the oil produced. }\end{array}$ & $65-70$ & $\begin{array}{l}\text { Asphalt extender, thermal } \\
\text { energy production, or as a } \\
\text { bitumen mix component. }\end{array}$ & $\begin{array}{c}\text { Denmark: 40,000, Spain: } \\
42,000\end{array}$ \\
\hline $\begin{array}{l}\text { EcoHuile (Sotulub) } \\
\text { (France) }\end{array}$ & $\begin{array}{l}\text { Mineral oils and some stable } \\
\text { synthetics in the presence of } \\
\text { alkaline additives. }\end{array}$ & $\begin{array}{l}\text { It does not require a final } \\
\text { step; this decreases the } \\
\text { investment cost of the } \\
\text { process. }\end{array}$ & $\begin{array}{l}\text { A base oil of poor } \\
\text { quality. }\end{array}$ & $82-92$ & & 125,000 \\
\hline \multicolumn{7}{|c|}{$\begin{array}{r}\text { Hydrotreatment } \\
\end{array}$} \\
\hline \multicolumn{7}{|c|}{ TFE + hydro-treatment } \\
\hline $\begin{array}{l}\text { CEP process } \\
\text { (Finland) }\end{array}$ & $\begin{array}{l}\text { It accepts used oil from } \\
\text { different sources: industrial } \\
\text { and motor, mineral and } \\
\text { synthetic oils. }\end{array}$ & $\begin{array}{l}\text { High operating and capital } \\
\text { costs. }\end{array}$ & $\begin{array}{l}\text { High quality base oils } \\
\text { (API II). }\end{array}$ & 70 & & 60,000 \\
\hline \multicolumn{7}{|c|}{ TDA+ hydro-treatment } \\
\hline $\begin{array}{c}\text { Revivoil } \\
\text { (Italy, Poland and Spain) }\end{array}$ & Use motor oil types. & $\begin{array}{c}\text { Operation and capital costs } \\
\text { higher. }\end{array}$ & $\begin{array}{l}\text { Products of comparable } \\
\text { quality to virgin base oils } \\
\text { meet the requirements of } \\
\text { API II. }\end{array}$ & 72 & $\begin{array}{l}\text { Asphalt and bituminous } \\
\text { membrane extender. } \\
\text { Hydro-treatment catalyst } \\
\text { regenerated and reused in } \\
\text { the process. }\end{array}$ & $\begin{array}{l}\text { Italy: 130,000, Poland: } \\
80,000 \text {, Spain: } 59,000\end{array}$ \\
\hline
\end{tabular}


Table 8. Cont

\begin{tabular}{|c|c|c|c|c|c|c|}
\hline Technology & Raw Material & Investment Costs & Product Quality & Yield \% & Waste & Plant Capacity (t/year) \\
\hline \multicolumn{7}{|c|}{ Solvent extraction + hydro-treatment } \\
\hline $\begin{array}{l}\text { Snamprogetti } \\
\text { (Italy) }\end{array}$ & Use motor oil types. & $\begin{array}{l}\text { Relatively expensive due to } \\
\text { PDA (propane deasphalting) } \\
\text { and hydro-treatment. }\end{array}$ & High quality base oils. & $74-80$ & Asphalt production. & 84,000 \\
\hline $\begin{array}{l}\text { Cyclon process } \\
\text { (Greece) }\end{array}$ & Use motor oil types. & $\begin{array}{l}\text { Operation and capital costs } \\
\text { higher. }\end{array}$ & High-quality base oils. & 72 & $\begin{array}{l}\text { Light hydrocarbon fuel used } \\
\text { in boiler oil heaters. }\end{array}$ & 40,000 \\
\hline CleanOil ORT (China) & Use motor oil types. & $\begin{array}{l}\text { Relatively expensive due to } \\
\text { PDA (propane } \\
\text { deasphalting), vacuum } \\
\text { distillation and } \\
\text { hydro-treatment. }\end{array}$ & $\begin{array}{l}\text { High quality Group II/II } \\
\text { + base oils, exceed } \\
\text { performance standards } \\
\text { (API) }\end{array}$ & 90 & Asphalt flux & 20,000 \\
\hline
\end{tabular}


The pretreatment of used oil that ETAPA currently carries out (water and sludge removal through sedimentation, centrifugation, and filtration) is similar to that used in the UAE [44] and Egypt [56]. Thus, the preliminary steps required for the solvent extraction process are already being performed. In the re-refining process through solvent extraction, a 1:3 oil-to-solvent ratio is proposed (where the solvents are blends of butanol + toluene + methanol or butanol $+\mathrm{KOH}$ ), following the processes used in the two aforementioned countries $[44,56]$. The solvent extraction process is followed by a vacuum distillation step for the recovery of solvents that will be reused in the process to remove metals (especially $\mathrm{Pb}$ and $\mathrm{Fe}$ ) [44]. For the finishing step, different adsorbents can be used. However, better results are obtained with alumina, bentonite, and activated bentonite. The use of almond and palm kernel powders can also be effective [44]. At the moment, ETAPA's Used Oil Collection Program sends the filtered and ceded oil sludge to the ECOTECNO Foundation attached to HOLCIM, where a thermal destruction of the waste is carried out with the endorsement of the local and regional Environmental Control Entity. The waste generated by the re-refining plants in Europe and China are used as a component in asphalt preparation and as fuel in boilers [66]. These could be an option for re-using the wastes of the re-refining processes since the city has a small asphalt production plant that could process all this by-product. The development of a re-refining plant with a capacity to process higher amounts of used oils than that currently collected in the city is suggested. Our estimates indicate that there could be up to $7330 \mathrm{t} /$ year of used oil to be processed in the proposed plant (which is around $10 \%$ of the total lubricant oil consumed in Ecuador; see Section 1). This amount would result from (a) a complete recovery of used oil in Cuenca; and (b) the contribution of neighboring cities in the South of Ecuador (e.g., Loja, Azogues, Machala, and other smaller cities) that are located at distances less than $220 \mathrm{~km}$ from Cuenca (Figure 5). According to [72], the added total number of cars in these cities is approximately double that in Cuenca. However, further work is necessary to better define the collection, transport, and storage logistics of used oil in those cities to comply with the requirements of a re-refining plant and Law 042. The benefit for Ecuador is enormous since the import of up to $7330 \mathrm{t} /$ year of lubricant could be avoided in these conditions. In addition to environmental and social benefits, the country could save around US\$ 30 million/year, according to data from the Central Bank of Ecuador [73], due to avoiding the import of lubricant oils.

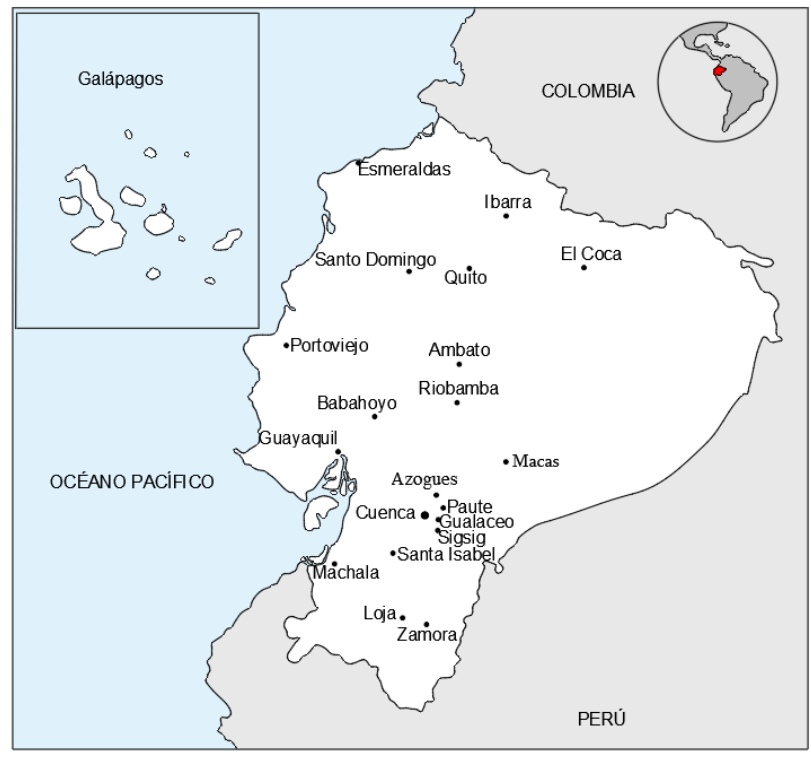

Figure 5. Map of Ecuador showing Cuenca and some neighboring cities that could supply used lubricant oils for the operation of a re-refining plant. 


\section{Conclusions}

Disposing of used lubricating oils by direct incineration causes damage to the environment while losing a non-renewable resource. A circular economy requires the reuse of used lubricating oils to reduce waste and environmental damage while promoting social benefits. While the current used oil collection system in Cuenca is primarily focused on avoiding spills and the collection of used oils, strategies to re-refine and therefore add value to these materials are important steps to consider. The work has found that the storage conditions of the used oil in the generators' premises do not significantly affect its properties. This result shows that the system currently used by used oil generators in Cuenca can be used for further processing and no changes to the system or logistics are required. The characterization of used oils in the city has shown that most of the properties are comparable to those of used oils in other countries (for example, the United Arab Emirates, Iraq, and Egypt). Some critical properties, such as the water content, are below those reported in the literature, which helps the re-refining process. Consequently, technologies to recover and add value to used oils in Cuenca must consider the experiences of other nations in the processing of similar used oils. European industries show great progress on the subject, as well as good recovery rates and quality of the regenerated product. The union of several methods improves the final product even more, but the economic investment increases. However, small- and medium-sized cities such as Cuenca do not generate large amounts of used oil in order to have plants with the same capacities as those in Europe. Therefore, the selection of treatment technology must also consider aspects such as the available market, operating costs, transportation, energy, and the quality of oil to be obtained. Due to the conditions in Cuenca, a good option is the solvent extraction process since it can be adapted by small-scale plants, providing adequate quality and performance of the products, as well as reducing negative environmental impacts. For the finish (improvement of color and odor), bentonite, a material that is available near the city, can be used. Furthermore, in Cuenca the initial step is already being carried out; that is, the filtration/dehydration and sedimentation process. Re-refining used oils in Cuenca and other medium-sized cities, whether in Latin America or elsewhere, is necessary to comply with the principles of a circular economy, taking advantage of non-renewable resources and contributing to the economy, society, and environment.

Author Contributions: Conceptualization, C.S.-A., J.C.-B. and D.A.-A.; methodology, C.S.-A., J.C.-B., M.R.P.-S. and D.A.-A.; sampling, J.C.-B. and D.A.-A.; software, C.S.-A. and F.G.-Á.; validation, C.S.-A., J.C.-B. and M.R.P.-S.; formal analysis C.S.-A., J.C.-B. and M.R.P.-S.; investigation, C.S.-A., J.C.-B., F.G.-Á. and D.A.-A.; data curation, C.S.-A. and F.G.-Á.; writing-original draft preparation, C.S.-A., J.C.-B. and F.G.-Á.; writing - review and editing, C.S.-A. and M.R.P.-S.; funding acquisition, J.C.-B. and D.A.-A. All authors have read and agreed to the published version of the manuscript.

Funding: This research was funded by the Research Department of the University of Cuenca (DIUC) through the project "Análisis y definición de estrategias y escenarios para el desarrollo de sistemas de mantenimiento industrial orientado a la eficiencia energética y amigable con el ambiente en la ciudad de Cuenca".

Institutional Review Board Statement: Not applicable.

Informed Consent Statement: Not applicable.

Data Availability Statement: The data presented in this study are available in this article.

Acknowledgments: The authors acknowledge Raul Pelaez-Garcia for English editing.

Conflicts of Interest: The authors declare no conflict of interest. The funders had no role in the design of the study; in the collection, analyses, or interpretation of data; in the writing of the manuscript, or in the decision to publish the results. 


\section{References}

1. References Agencia de Regulación y Control Hidrocarburifero [ARCH]. Reglamento Elaboración Aceites, Lubricantes Para Uso de Automotores. Available online: https://www.controlhidrocarburos.gob.ec/wp-content/uploads/MARCO-LEGAL-2016 /Registro-Oficial-Suplemento-621-Res.-ARCH-3.pdf (accessed on 12 June 2019).

2. Mensah-Brown, H. Re-refining and recycling of used lubricating oil: An option for foreign exchange and natural resource conservation in Ghana. ARPN J. Eng. Appl. Sci. 2015, 10, 797-801.

3. El-Fadel, M.; Khoury, R. Strategies for vehicle waste-oil management: A case study. Resour. Conserv. Recycl. 2002, 33, 75-91. [CrossRef]

4. Almeida Streitwieser, D.; Jativa Guzmán, F.; Aguirre Ortega, B. Conversión de aceite lubricante usado de automóviles a Diésel \#2. Rev. Digit. VI Congr. Cienc. Tecnol. 2011. Available online: http://repositorio.espe.edu.ec/handle/21000/3483 (accessed on 6 February 2019).

5. Fong Silva, W.; Quiñones Bolaños, E.; Tejada Tovar, C. Physical-chemical caracterization of spent engine oils for its recycling Caracterización físico-química de aceites usados de motores para su reciclaje. Prospectiva 2017, 15, 135-144. [CrossRef]

6. Ministerio del Medio Ambiente [MMA]. Evaluación Económica, Ambiental y Social de la Implementación de la REP en Chile. Available online: https://mma.gob.cl/wp-content/uploads/2015/07/Publicacion-impactos-2012.pdf (accessed on 28 December 2019).

7. Botas, J.A.; Moreno, J.; Espada, J.J.; Serrano, D.P.; Dufour, J. Recycling of used lubricating oil: Evaluation of environmental and energy performance by LCA. Resour. Conserv. Recycl. 2017, 125, 315-323. [CrossRef]

8. Parry, B.J. Oil Recycling. In Kirk-Othmer Encyclopedia of Chemical Technology; Terrapure Environmental: North Vancouver, BC, Canada, 2016; pp. 1-16. ISBN 0471238961.

9. Martelli-Tristão, J.A.; Valentini-Tristão, V.T.; Frederico, E. O processo de reciclagem do óleo lubrificante. Rev. Ibero-Am. Ciênc. Ambient. 2017, 8, 224-238. [CrossRef]

10. CONAMA. A Importância da Destinação Correta do Óleo Lubrificante Usado-A Logística Reversa Como Instrumento na Aplicação da Resolução CONAMA No 362/2005. Available online: https:/ / www.linkedin.com/pulse/importância-da-destinaç ao-correta-do-óleo-usado-logística-ramos / (accessed on 29 November 2019).

11. SINDIRREFINO—Processo Industrial/Rerrefino. Available online: https://www.sindirrefino.org.br/institucional/a-instituicao (accessed on 17 December 2020).

12. Compañía Industrial Lima S.A. [CILSA]. Protegemos el Medio Ambiente. Available online: https://www.cilsaperu.com/leer.html (accessed on 30 May 2020).

13. BIOFACTOR S.A. Available online: http:/ / biofactorsa.com/ (accessed on 30 May 2020).

14. Nueva Energía S.A. Available online: https://nuevaenergiasa.com.ar/ (accessed on 30 May 2020).

15. Muñoz, E.; Montoya, D.; Muñoz, A. La Re-Refinación: Una Alternativa a la Mano Para la Disposición Adecuada de Aceites usados (1). Available online: http:/ / nuevagaceta.co/inicio/re-refinacion-alternativa-disposicion-adecuada-de-aceites-usados (accessed on 30 May 2020).

16. BID. BID Lab Apoya Creación de Primera Planta de Recuperación de Aceite en Centroamérica I IADB. Available online: https: //www.iadb.org/es/noticias/bid-lab-apoya-creacion-de-primera-planta-de-recuperacion-de-aceite-en-centroamerica (accessed on 29 November 2019).

17. Banco Central del Ecuador [BCE]. Evolución de la Balanza Comercial Enero-Julio/2018. Available online: https:/ / contenido.bce. fin.ec/documentos/Estadisticas/SectorExterno/BalanzaPagos/balanzaComercial/ebc201812.pdf (accessed on 25 January 2019).

18. Ministerio del Ambiente y Agua [MAE]. Instructivo para la Gestión Integral de Aceites Lubricantes Usados y Envases VacíosApel. Available online: http:/ / apel.ec/biblioteca/mae-instructivo-para-la-gestion-integral-de-aceites-lubricantes-usados-yenvases-vacios/ (accessed on 30 May 2020).

19. Diario el Comercio Convenios en cinco ciudades del Ecuador para Reciclar Aceites Usados. Available online: https://www. elcomercio.com/actualidad/convenios-ciudades-ecuador-reciclar-aceites.html (accessed on 29 November 2019).

20. ETAPA. EP—Servicios de Telefonía, Televisión, Internet, Agua Potable, Alcantarillado de Cuenca-Ecuador > Información > Gestión Ambiental > Gestión Ambiental Urbana > Programa de Recolección de Aceites. Available online: https:/ / www.etapa.net. ec/informacion/gestion-ambiental/gestion-ambiental-urbana/programa-de-recoleccion-de-aceites (accessed on 31 March 2020).

21. Navarro-Nuñez, W. Estado Situacional del Manejo del Aceite Lubricante Usado en la Ciudad de Ayacucho y Propuesta de Disposición Final. Master's Thesis, Universidad de Piura, Piura, Perú, 2014.

22. Pinheiro, C.T.; Ascensão, V.R.; Cardoso, C.M.; Quina, M.J.; Gando-Ferreira, L.M. An overview of waste lubricant oil management system: Physicochemical characterization contribution for its improvement. J. Clean. Prod. 2017, 150, 301-308. [CrossRef]

23. Jaramillo, D.; Redrován, L.; Urgilés, D. Analisis Técnico de la Vida Útil de un Lubricante de Aceite Mineral, para Motores de Combustion Interna a Gasolina de los Vehículos de Servicios de Taxis en la Ciudad de Cuenca. Bachelor's Thesis, Universidad Politécnica Salesiana, Cuenca, Ecuador, 2011.

24. Fundación PRO-AMBIENTE Manejo Ambientalmente Racional de Aceites Lubricantes Usados. Available online: https://es. slideshare.net/JGNathyvidad/aceites-usados-39623939 (accessed on 30 November 2019).

25. Peñafiel Chiriboga, S.L. Caracterización del Manejo de Aceites de Desecho de Automóviles e Hidráulicos de Origen Industrial en la Ciudad de Cuenca. Bachelor's Thesis, Universidad de Cuenca, Cuenca, Ecuador, 2017. 
26. ASTM International Standard. Practice for Calculating Viscosity Index from Kinematic Viscosity; D 2270-04; ASTM International: West Conshohocken, PA, USA, 2009; pp. 1-6.

27. ASTM International Standard. Test Method for Density, Relative Density, and API Gravity of Liquids by Digital Density Meter; D4052-11; ASTM International: West Conshohocken, PA, USA, 2011; pp. 1-8.

28. ASTM International Standard. Test Method for Acid Number of Petroleum Products by Potentiometric Perchloric Acid Titration; D 2896-03; ASTM International: West Conshohocken, PA, USA, 2003; pp. 1-7.

29. ASTM International Standard. Test Method for Flash and Fire Points by Cleveland Open Cup Tester; D 92-05; ASTM International: West Conshohocken, PA, USA, 2005; pp. 1-10.

30. ASTM International Standard. Practice for Calculating Viscosity Index from Kinematic Viscosity at 40 and $100{ }^{\circ} \mathrm{C}$; D $2270-93$ (Reapproved 1998); ASTM International: West Conshohocken, PA, USA, 1993; pp. 1-6.

31. ASTM International Standard. Test Method for Determination of Wear Metals and Contaminants in Used Lubricating Oils or Used Hydraulic Fluids by Rotating Disc Electrode Atomic Emission Spectrometry; D6595-16; ASTM International: West Conshohocken, PA, USA, 2011; pp. 1-6.

32. De la Fuente Fernandez, S. Análisis de Conglomerados. Available online: https://www.academia.edu/32046069/Análisis_ Conglomerados_Santiago_de_la_Fuente_Fernández (accessed on 18 September 2018).

33. Hines, W.; Montgomery, D.; Borror, C. Probabilidad y Estadística para Ingeniería, 3rd ed.; Compañía Editorial Continental: Mexico City, Mexico, 2005; ISBN 970240553X.

34. Widman, R. Interpretando el Reporte de Análisis de Aceite. Available online: http://www.mantenimientomundial.com/notas/ w46.pdf (accessed on 6 February 2019).

35. Widodo, S.; Ariono, D.; Khoiruddin, K.; Hakim, A.N.; Wenten, I.G. Recent advances in waste lube oils processing technologies. Environ. Prog. Sustain. Energy 2018, 37, 1867-1881. [CrossRef]

36. Gómez Estrada, Y. Contribución al Desarrollo y Mejora para la Cuantificación de la Degradación en Aceites Lubricantes Usados de MCIA a Través de la Técnica de Espectrometría Infrarroja por Transformada de Fourier (FT-IR). Ph.D. Thesis, Universitat Politècnica de València, Valencia, Spain, 2013.

37. Terpel Terpel Oiltec 20W-50 Titanio. Available online: https:/ /www.terpel.com/Plantillas/Terpel/Descargables/Lubricantes/ TerpelOiltec20W-50Titanio.pdf (accessed on 30 June 2020).

38. Noria Corporation. Q \& A: ¿Qué es el TBN y qué Indica en el Análisis de Aceite? Noria Latín América. Available online: http:/ / noria.mx/lublearn/q-a-que-es-el-tbn-y-que-indica-en-el-analisis-de-aceite/ (accessed on 30 November 2019).

39. Mang, T.; Dresel, W. Lubricants and Lubrication, 2nd ed.; WILEY-VCH: Weinheim, Germany, 2007; ISBN 9783527610341.

40. Arellano, L. Proyecto Planta de Reciclaje de Aceites Usados por Extracción por Solvente; Asesorías y Proyectos Ribotta: Valparaíso, Chile, 2008.

41. Amesty, R.; De Turris, A.; Rojas, D.; Hurtado, A.; Medrano, J.; López, Y. Characterization of Oil Lubricant Automotive for Reuse. Redieluz 2015, 5, 43-48.

42. Villanueva Torres, C. Diseño de una Planta Piloto para Desarrollar Tecnología de Extracción con Solvente para Tratamiento de Aceites Usados. Bachelor's Thesis, Universidad Nacional de Ingeniería, Lima, Perú, 2005.

43. Moya Díaz, L. Desde el Aceite Lubricante Usado Hasta su Puesta en el Mercado Tras Su Regeneración. Master's Thesis, Fundación Escuela de Organización Industrial, Madrid, Spain, 2010.

44. Abdel-Jabbar, N.M.; Al Zubaidy, E.A.H.; Mehrvar, M. Waste lubricating oil treatment by adsorption process using different adsorbents. World Acad. Sci. Eng. Technol. 2010, 62, 9-12.

45. Boughton, B.; Horvath, A. Environmental Assessment of Used Oil Management Methods. Environ. Sci. Technol. 2004, 38, 353-358. [CrossRef]

46. Syrmanova, K.K.; Kovaleva, A.Y.; Kaldybekova, Z.B.; Botabayev, N.Y.; Botashev, Y.T.; Beloborodov, B.Y. Chemistry and recycling technology of used motor oil. Orient. J. Chem. 2017, 33, 3195-3199. [CrossRef]

47. Owolabi, R.; Amosa, M.K. Some Physico-Chemical and Adsorptive Reclamation Strategies of Spent Automobile Engine Lubricating Oil. J. Eng. Res. 2017, 22, 98-106.

48. Abdulkareem, A.S.; Afolabi, A.S.; Ahanonu, S.O.; Mokrani, T. Effect of treatment methods on used lubricating oil for recycling purposes. Energy Sources, Part A Recover. Util. Environ. Eff. 2014, 36, 966-973. [CrossRef]

49. Korchak, B.; Hrynyshyn, O.; Chervinskyy, T.; Polyuzhin, I. Application of vacuum distillation for the used mineral oils recycling. Chem. Chem. Technol. 2018, 12, 365-371. [CrossRef]

50. Ramadass, K.; Megharaj, M.; Venkateswarlu, K.; Naidu, R. Ecological implications of motor oil pollution: Earthworm survival and soil health. Soil Biol. Biochem. 2015, 85, 72-81. [CrossRef]

51. Zając, G.; Szyszlak-Bargłowicz, J.; Słowik, T.; Kuranc, A.; Kamińska, A. Designation of chosen heavy metals in used engine oils using the XRF method. Polish J. Environ. Stud. 2015, 24, 2277-2283. [CrossRef]

52. Hamawand, I.; Yusaf, T.; Rafat, S. Recycling of waste engine oils using a new washing agent. Energies 2013, 6, 1023-1049. [CrossRef]

53. Mohammed, R.R.; Ibrahim, I.A.R.; Taha, A.H.; McKay, G. Waste lubricating oil treatment by extraction and adsorption. Chem. Eng. J. 2013, 220, 343-351. [CrossRef]

54. Muhammad, Q.; Tariq, M.A.; Mazhar, H. Physico-chemical characteristics of Pakistani used engine oils. J. Pet. Technol. Altern. Fuels 2016, 7, 13-17. [CrossRef] 
55. Elkhaleefa, A.M. Waste Engine Oil Characterization and Atmospheric Distillation to Produce Gas Oil. Int. J. Eng. Adv. Technol. 2016, 5, 6-8.

56. Osman, D.I.; Attia, S.K.; Taman, A.R. Recycling of used engine oil by different solvent. Egypt. J. Pet. 2018, 27, 221-225. [CrossRef]

57. U.S. Environmenteal Protection Agency (EPA). Used Oil Management Program. Available online: https://archive.epa.gov/ wastes/conserve/materials/usedoil/web/html/index.html (accessed on 29 November 2019).

58. Speight, J.G.; Exall, D.I. Refining Used Lubricating Oils; CRC Press: Boca Raton, FL, USA; Taylor and Francis: Boca Raton, FL, USA, 2014; ISBN 9781466551497.

59. Emam, E.A.; Shoaib, A.M. Re-refining of Used Lube Oil, II- by Solvent/Clay and Acid/Clay-Percolation Processes. ARPN J. Sci. Technol. 2012, 2, 1034-1041.

60. Isah, A.G.; Abdulkadir, M.; Onifade, K.R.; Musa, U.; Garba, M.U.; Bawa, A.A.; Sani, Y. Regeneration of used engine oil. Lect. Notes Eng. Comput. Sci. 2013, 1 LNECS, 5-8.

61. Stan, C.; Andreescu, C.; Toma, M. Some aspects of the regeneration of used motor oil. Procedia Manuf. 2018, 22, 709-713. [CrossRef]

62. Salem, S.; Salem, A.; Agha Babaei, A. Preparation and characterization of nano porous bentonite for regeneration of semi-treated waste engine oil: Applied aspects for enhanced recovery. Chem. Eng. J. 2015, 260, 368-376. [CrossRef]

63. García González, M.T. Regeneración de Aceites Lubricantes Usados Mediante Extracción. Available online: https://dialnet. unirioja.es/servlet/tesis?codigo=105028 (accessed on 30 November 2019).

64. Uribe, R. Investigaciones de Materias Primas Minerales No Metálicas en el Ecuador. Rev. Politec. 2015, 36, 34. [CrossRef]

65. Haro, C.; De La Torre, E.; Aragón, C.; Guevara, A. Regeneración de arcillas de blanqueo empleadas en la decoloración de aceites vegetales comestibles. Rev. EPN 2014, 34, 1-8.

66. Kupareva, A.; Mäki-Arvela, P.; Murzin, D.Y. Technology for rerefining used lube oils applied in Europe: A review. J. Chem. Technol. Biotechnol. 2013, 88, 1780-1793. [CrossRef]

67. Maghsoodi, A.I.; Afezalkotob, A.; Ari, I.A.; Maghsoodi, S.I.; Hafezalkotob, A. Selection of waste lubricant oil regenerative technology using entropy-weighted risk-based fuzzy axiomatic design approach. Informatica 2018, 29, 41-74. [CrossRef]

68. Jafari, A.J.; Hassanpour, M. Analysis and comparison of used lubricants, regenerative technologies in the world. Resour. Conserv. Recycl. 2014, 103, 179-191. [CrossRef]

69. Nwachukwu, A. Review and assessment of mechanic village potentials for small scale used engine oil recycling business. Afr. J. Environ. Sci. Technol. 2012, 6, 464-475. [CrossRef]

70. Oladimeji, T.E.; Sonibare, J.A.; Omoleye, J.A.; Emetere, M.E.; Elehinafe, F.B. A review on treatment methods of used lubricating oil. Int. J. Civ. Eng. Technol. 2018, 9, 506-514.

71. CleanOil Limited-China's Most Advanced and Cleanest Oil Re-Refiner. Available online: http://www.cleanoil.com.hk/ (accessed on 26 December 2020).

72. AEADE SECTOR AUTOMOTOR en Cifras. Available online: http://www.aeade.net/wp-content/uploads/2017/03/Sector-encifras_6-Marzo-2017.pdf (accessed on 30 December 2019).

73. Ecuador Evolución de la Balanza Comercial Enero-Diciembre/2019. Subgerencia Program. y Regul. Available online: https: // contenido.bce.fin.ec/documentos/Estadisticas/SectorExterno/BalanzaPagos/balanzaComercial/ebc202002.pdf (accessed on 16 February 2019). 